\title{
Determination of the flood volume by the aspects of peak flow and flood hydrograph at the level of the city of Biskra, Wadi Biskra watershed, Algeria.
}

amel Boumessenegh ( $\square$ carinacapour84@gmail.com )

University of Mustapha Ben Boulaid Batna 2: Universite Batna 2 https://orcid.org/0000-0001-68851643

hadda dridi

University of Mustapha Ben Boulaid Batna 2: Universite Batna 2

\section{Manuscript}

Keywords: Return periods, flood flows, peak flows, gradex method, flood volume, flood hydrograph

Posted Date: February 10th, 2021

DOI: https://doi.org/10.21203/rs.3.rs-203909/v1

License: (c) (i) This work is licensed under a Creative Commons Attribution 4.0 International License. Read Full License 


\section{Abstract}

The peak flow of a flood can be determined by several empirical methods. Among these methods, the Gradex method is used in this work to estimate the project flood and the volumes corresponding to the flows. This approach has made it possible to recognize the flow of different frequencies by aspects of the peak flow and the flood hydrograph. The study was based on the maximum annual daily rainfall for a long series of observations (47 years), and on the intensity-duration-frequency (IDF) curves of the four rainfall stations Biskra, T'kout, Djemoura, and El kantara; located in the watershed of Oued Biskra.

The application of the Gradex method has allowed to approach the maximum flow of floods at the level of the outlet which is located at the entrance of the city of Biskra; for the rare frequency of occurrence (return periods ranging from 10 to 1000 years).

\section{Introduction}

Algeria, like other countries in the world, suffers from water resource management problems. These require a good knowledge of the spatial and temporal variability of the hydrological regime at the scale of catchment areas (floods and low water levels), in order to achieve a good management of flood risks, whether at the scale of catchment areas or at the scale of alluvial plains. This study focuses on the phenomenon of extreme flood runoff of the Oued Biskra at the level of the city of Biskra. These floods constitute a risk for all the components of the studied watershed. Indeed, the overflows that have occurred in recent years, particularly during the years 2000 and 2010, have caused considerable human losses and material damage (Layan, 2008).

\section{Geographic Context Of The Study Area}

The Wilaya of Biskra is located in the South-East of Algeria, it occupies an area of $21671 \mathrm{Km} 2$, its altitude is 128 meters / sea level. (ANAT). The case study and analysis is Biskra, an Algerian Saharan [27] city located at $34^{\circ} 48$ North (latitude) and $05^{\circ} 44$ East (longitude) [1]. Figure $n^{\circ} 01$.

The climate of Biskra is characterized by a very hot and dry summer, the average temperature is $43.5^{\circ} \mathrm{C}$, (figure $2(a)$ ), the average relative humidity is $12 \%$, (figure $2(b)$ ), and a very cold winter (average minimum temperature of $4{ }^{\circ} \mathrm{C}$, average maximum relative humidity of $89 \%$ ). Precipitation is rare and does not exceed 31 days per year. Biskra is located in the arid region, according to the aridity index of 'Martonne', [2].

The summer months, June, July, August and until September, are hot months, with average maximum temperatures of 36.5 to $39^{\circ} \mathrm{C}$. On the other hand, the months of November to April are considered cold with average minimum temperatures of 11.7 to $8.4^{\circ} \mathrm{C}$.

Incident solar radiation is very intense and of the order of $7680 \mathrm{Wh} / \mathrm{m} 2$, on a horizontal plane during the month of July, (figure 3(a)), which corresponds to a sunshine duration of 383 hours, (figure 3(b)), and 
which can exceed 12 hours per day.

In winter, it reaches its minimum during the month of December for an intensity of $2712 \mathrm{Wh} / \mathrm{m} 2$, which corresponds to a sunshine duration of 219 hours/month, or 7 hours/day [3]. All this contributes to the harsh climate of the city of Biskra. (Figure $4 a$ and $b$ ).

\subsection{Presentation of the Wadi Biskra watershed}

Wadi Biskra Limited to Biskra, this sub-basin covers an area of $2787 \mathrm{~km}^{2}$, almost all of which belongs to the domain of the runoff slopes. Wadi Biskra is formed by the meeting of the two large wadis El Haï (subbasin of Wadi El Hai), and Wadi Djemoura (sub-basin of Wadi Djemoura), which drain respectively an area of 1788 and $906 \mathrm{~km} 2$, whose confluence gives rise to Wadi Biskra (the sub-basin of the complementary Wadi Biskra) covers an area of $93 \mathrm{~km} 2$ at an altitude of $200 \mathrm{~m}$ (Figure 05 (a)).

Wadi Biskra has its source in the region of Zgag (Western Aurès), at an altitude of $2000 \mathrm{~m}$. It flows into the Melrhir, $25 \mathrm{~m}$ below sea level, after a course of about $194 \mathrm{~km}$. Its profile, with a very steep slope to El Kantara, is that of a relatively young wadi (Figure $05(b)$ ).

During the period 1938-1951, 43 months of flooding were observed at Biskra, an average of nearly 4 per year.

\section{Objectives And Methodology}

Given the absence of daily flow gauges to facilitate the statistical analysis of ancient floods, the hydrological study was used. This approach aims at the recognition of project floods by the aspects of peak flow and flood hydrograph. The flood study was carried out using the Gradex method to achieve two main objectives; namely the estimation of peak flows (Qp) at the outlet of the studied catchment area for return periods ranging from 10 to 1000 years, and the determination of the shape of the flood hydrograph and the estimation of flood volumes.

The Gradex method, therefore, aims at finding the maximum flood flows for rare to very rare frequencies of occurrence (return time more than 100 years). It is particularly applicable when there is a long series of rainfall in the basin, thus allowing to make the most of all available data.

In general, more rainfall information is often available (Meylan and Musy, 1999).

This method was introduced by Guillot and Duband (1967) and has since been used by several authors such as Naghettini et al (1996). Gradex is a very suitable method for watersheds for which flow data are not available (Zemzami et al., 2012).

This method is based on the following assumptions:

- the maximum flows sought are only caused by maximum rainfall, uniformly distributed over the basin. Thus, there are no different origins of flood formation. 
- The maximum rainfall and the corresponding flow rates follow the same statistical distribution law, called the extremes because of the nature of the phenomenon sought (rare floods). This expresses above all the fact that the asymptotic behaviour of the rainfall and flow distribution laws is identical. Gumbel's law (Gumbel, 1958) is often used for this purpose, and only in this case is the exponential nature of this distribution described by the slope of the observed rainfall adjustment line, measured on a suitable probability diagram. The slope of this line is the gradient of this exponential distribution. The Gradex method was applied according to the following steps:

- Gumbel's law adjustment of maximum daily rainfall and determination of Pjmax $(T)$ for $T$ ranging from 2 to 1000 years.

-Determination of the daily Gradex (Gp(24)).

-Choice of a unit hydrograph.

-Calculation of the Rain Gradex over the concentration time $\mathrm{Gp}(\mathrm{Tc})$ from the Rain Gradex in 24 hours.

-Calculation of the reference peak flow $\mathrm{Qp}(\mathrm{T}$ decennial return period) using Caquot's empirical formulas.

-Calculation of the peak flow rates and runoff water levels for each return period using the Gradex method.

\section{Available Data}

The present study was based on the annual maximum daily rainfall and the Intensity-Duration-Frequency (IDF) curves of the seven stations located in the Oued Biskra watershed (see Table 01).

The Montana coefficients are necessary for the application of certain formulas related to the Gradex method (Musy, 1998). The parameters ( $a$ and $b$ ) adopted for the estimation of the point flow are obtained from the curves (IDF) of the meteorological stations of Biskra, Batna, T'kout, Menaa, Djemoura, Bouzina and El kantara. (fig.06).

The watershed concerned by this study was delimited by the Arc gis software. The geometric characteristics (area, length of the talweg, maximum gradient...) of the upstream part of the Oued Biskra watershed are represented in the table below (Table.2).

\section{Concentration Time}

The concentration time Tc of the water on a watershed is defined as the maximum amount of time required for a drop of water to travel the hydrological path from a point as far as possible from the outlet to reach the outlet.

Theoretically, Tc is estimated to be the duration between the end of net rainfall and the end of runoff. In practice, the concentration time can be deduced from field measurements or can be estimated with the 
help of formulas that are usually empirical.

In this study we calculated the concentration time by three empirical formulas :

5.1 Giondotti's formula :

$$
T_{c}=\frac{4 \sqrt{\mathrm{BS}}+1,5 \mathrm{~L}}{0,8 \sqrt{\operatorname{Med} \mathrm{H}-\operatorname{Min} \mathrm{H}}}
$$

BS : basin surface $\left(\mathrm{km}^{2}\right)$.

$\mathrm{L}$ : of the main Talweg $(\mathrm{Km})$.

Med $\mathrm{H}$ : medium height $(\mathrm{m})$.

Min $\mathrm{H}$ : minimum height $(\mathrm{m})$.

5.2 The SCS formula (Soil Conservation Service)

$$
t c=\left[\frac{0,87 * L}{H}\right]^{0,385}
$$

Tc: Concentration time in hours

$\mathrm{L}$ : of the main Talweg $(\mathrm{Km})$.

$H$ : Difference between the end points of the talweg $(m)$.

\section{3 The KIRPICH formula}

$$
T_{c}=0,6615 *(\mathrm{~L})^{0,77} *(\mathrm{I})^{-0,385}
$$

Tc: Concentration time in hours

$L$ : length of main watercourse $(\mathrm{Km})$.

I : Average longitudinal slope of the watershed $(\mathrm{m} / \mathrm{m})$.

The values adopted are the averages of the results of the three formulas. (Table 3).

Among the results obtained in Table 3; we opt for the result derived from the law of Giandotti because it is the formula, which takes into account the majority of the geomantic parameters of the watershed. $(\mathrm{Tc}=9.60 \mathrm{~h})$. 
Tc wadi El Hai=15 hours and 11,47 hour s for wadi Djemoura. The sub-basin of the complementary Biskra wadi has a concentration time; 9,62 hours.

\section{Application And Discussion Estimation Of Gradex}

To estimate the Gradex, different approaches are possible. When the observation series is long $(>30$ years) the simplest and most efficient is to directly adjust the maximum annual rainfall to a Gumbel's law. When the series is shorter, it is often preferable to work on rainfall above a threshold (number of rains above the threshold adjusted to a fish law, height of this rainfall adjusted to a Fuller's law (Laborde, 2000).

It is generally accepted that about 15 years of observations provide a relatively reliable estimate of Gradex. This way of estimating Gradex makes it possible to extrapolate precipitation to return periods of several thousand years (Duband, 1982).

\section{Extreme Rainfall Heights}

In this study, the daily maximum rainfall was adjusted from meteorological stations in the Wadi Biskra catchment area; for a fairly long series of observations (47 years) using Gumbel's law, this adjustment made it possible to estimate rainfall values for different return frequencies (Fig. 7). Moreover, this Gradex presents a constancy regardless of the period over which the maximum rainfall is taken.

The graphs obtained by the Gradex method for the Biskra Wadi Watershed and its sub-basins are presented in Fig. 08.

\section{Flood Hydrograph}

This method consists of plotting the curve from two parabolic equations, one for the rising flood and the other for the falling flood (Sghara, 2013).

Figure 09 shows the flood hydrographs for the Biskra Wadi and its catchment areas.

\section{Results And Discussion}

Based on the results obtained, we have concluded that the Gradex method is the most optimal method for determining the maximum flow rates for the Biskra Wadi basin.

The flood hydrographs established for the Biskra wadi watershed and its sub-basins allow to see the evolution of floods in time.

Finally, a more or less varied evaluation made it possible to fix the values of the floods crossing the study zone which will allow us to make the dimensioning and the hydraulic calculation of the protection work of this center against the risks of floods. 
The knowledge of the threshold flow a allowed us to draw synthetic single frequency hydrographs, which are essential elements for the input of hydrodynamic models in order to determine the flood hazard characterized by a return period T. It was found that the station of Biskra (which controls the large basin of Wadi Biskra) is characterized by a very important quantile for large return periods, followed by the station of Wadi El Hai, then the station of Wadi Djemoura and finally the station of Tkout (which controls the complementary Wadi Biskra).

\section{Conclusion}

The hydrology study conducted by applying the Gradex method resulted in a flow rate ranging from 9y-è3 to $2396 \mathrm{~m} 3 / \mathrm{s}$ for periods ranging from 10 to 1000 years. These results constitute a useful document for hydraulic modeling that allows the calculation of flow profiles and flood propagation in rivers.

Indeed, the hydrological study constitutes the foundation on which all river hydraulic modelling is built, allowing flood forecasting and hydrological risk management in flood plains.

The flood hydrographs established for the Wadi Biskra watershed and its sub-basins allow to see the evolution of floods over time.

$\operatorname{Tr}$ (Finally, a more or less varied evaluation allowed us to fix the values of the floods crossing the study area which will allow us to make the dimensioning and the hydraulic calculation of the protection work of this center against the risks of floods.

\section{References}

[1] M. Joannon, 'Développement et Mutations au Sahara Maghrébin' J. Bisson, In: Mediterranean, volume 76, 1992.

[2] A. Mahimoud, he Impact of New Urban Forms on the Microclimate of a Dry Belonging City - The Case of West Zhun in Biskra', Sciences and Technology D, №31, pp. 81 - 88, 2010, University Mentouri Constantine, Algeria.

[3] A. Hanafi, The Public Spaces between the Logic of Design and Daily Use / Case of Places and Squares of the City of Biskra / Algeria, 444 p., Université de Biskra, Algérie, Juin 2010.

[4] A. Matzarakis and B. Amelung, 'Physiological Equivalent Temperature as Indicator for Impacts of Climate Change on Thermal Comfort of Humans', 1996.

[5] H. Mayer, 'Another Kind of Environmental Stress: Thermal Stress', WHO, Collaborating Centre for Air Quality Management and Air pollution Control, Newsletters, 1996.[6] M.H. Nikolopoulou, N. Baker and K. Steemers, 'Thermal Comfort in Outdoor Urban Spaces', In Proceedings PLEA 1998: Environmentally Friendly Cities. James. 1998. 
[6] ABHS, (2005), Study of the protection of the city of Boulemane against floods. Sebou Hydraulic Basin Agency. 2004228/Ml/E/Hydrology-A0.

[7] Duband, D. (1982), In-depth statistical hydrology. Ecole national supérieure d'hydraulique de Grenoble. pp. II-11.

[8] Guillot, P. and Duband, D. (1967), he gradex method for calculating the probability of floods from rainfall, in Floods and Their Computation. Proceedings of the Leningrad Symposium, IASH Publ. 84: 560569.

[9] Gumbel, E.J. (1958), - Statistics of Extremes. Columbia University Press, ISBN 0-483- 43604-

[10] Laborde, J.P. (2000), - Element surface hydrology. University of Nice - Sophia Antipolis. Ed. 2000, pp $66,82,117,119$.

[11] Naghettini, M. Potter, K.W. and Illangasekare, T. (1996), - Estimating the upper tail of flood- peak frequency distributions using hydrometeorological information. Water Resources Research, Vol. 32: 17291740. http://www.agu.org/pubs/crossref/1996/96WR00200.shtml Zemzami, M.

[12] Benaabidate, L. Layan, B. and Dridri, A. (2012), - Design flood estimation in ungauged catchments and statistical characterization using principal components analysis: application of Gradex method in Upper Moulouya. Hydrological Processes, DOI: 10.1002/hyp.9212.

http://onlinelibrary.wiley.com/doi/10.1002/hyp.9212/abstract.

\section{Tables}

Table. 1 Coordinates of rainfall stations and controlled sub-basins

\begin{tabular}{|c|c|c|c|c|c|}
\hline \multirow[b]{2}{*}{ Station } & \multirow[b]{2}{*}{ Code NWRA ${ }^{(1)}$} & \multicolumn{3}{|c|}{ Lambert } & \multirow[t]{2}{*}{ Under controlled basin } \\
\hline & & $\mathbf{x}$ & Y & $\begin{array}{l}\text { Altitude } \\
\text { (m) }\end{array}$ & \\
\hline \multirow[t]{2}{*}{ Biskra } & 06.14 .16 & 777 & 178 & 120 & Wadi basin \\
\hline & & & & & Biskra \\
\hline T'kout & 06.15 .05 & 828,5 & 211,25 & 980 & Complementary Biskra wadi sub-basin \\
\hline Djemoura & 06.13 .05 & 786,5 & 201,6 & 545 & Djemoura wadi sub-basin \\
\hline El kantara & 06.12 .06 & 774,7 & 217,4 & 513 & El Hai wadi sub-bassin \\
\hline
\end{tabular}

\section{(1) : national water resources agency.}


Tab.2 Geometric characteristics of the study area

\begin{tabular}{|c|c|c|c|c|c|c|c|c|}
\hline & $\begin{array}{l}\text { BS } \\
\mathrm{Km}^{2}\end{array}$ & $\begin{array}{l}\mathrm{L} \\
\mathrm{Km}\end{array}$ & $\begin{array}{l}\underset{H}{\operatorname{Max}} \\
\mathrm{m}\end{array}$ & $\begin{array}{l}\underset{H}{\operatorname{Min}} \\
\mathbf{m}\end{array}$ & $\begin{array}{l}\text { Max el } \\
\text { m }\end{array}$ & $\begin{array}{l}\text { Med } \\
\mathrm{H} \\
\mathrm{m}\end{array}$ & $\begin{array}{l}\mathrm{P} \\
\mathrm{Km}\end{array}$ & SI \\
\hline \multicolumn{9}{|l|}{ Biskra } \\
\hline \multicolumn{9}{|c|}{ under basin wadi } \\
\hline El Hai & 1788 & 107 & 2091 & 956 & 622 & 200 & 229 & 1,52 \\
\hline \multicolumn{9}{|c|}{ under basin wadi } \\
\hline Djemoura & 906 & 93 & 2321 & 998 & 505,07 & 200 & 184 & 1,71 \\
\hline \multicolumn{9}{|c|}{$\begin{array}{l}\text { complementary wadi biskra sub- } \\
\text { basin }\end{array}$} \\
\hline & 93 & 57 & 1270 & 410 & 163,797 & 150 & 99 & 2,87 \\
\hline
\end{tabular}

BS : basin surface

$\mathbf{L}$ : of the main Talweg

Max $\mathrm{H}$ : maximum height

Min $\mathrm{H}$ : minimum height

Max el : Maximum elevation

Med $\mathrm{H}$ : medium height

P : perimeter

SI: shape index.

Tab.3. Concentration time in hours for Oued Biskra. 


\begin{tabular}{|c|c|c|c|c|}
\hline & Giondotti & Kirplich & CSC & Values \\
\hline & & & & adopted \\
\hline $\begin{array}{l}\text { Biskra wadi } \\
\text { basin }\end{array}$ & 9,60 & 8,69 & 10,98 & 9,60 \\
\hline $\begin{array}{l}\text { sub-basin of } \\
\text { El Hai wadi }\end{array}$ & 15 & 12,44 & 16,03 & 15 \\
\hline $\begin{array}{l}\text { sub-basin of } \\
\text { Djemoura } \\
\text { wadi }\end{array}$ & 11,47 & 10,62 & 12,91 & 11,47 \\
\hline $\begin{array}{l}\text { Sub-basin of } \\
\text { Biskra } \\
\text { comlementary } \\
\text { wadi }\end{array}$ & 9,62 & 8,67 & 10,95 & 9,62 \\
\hline
\end{tabular}

Figures

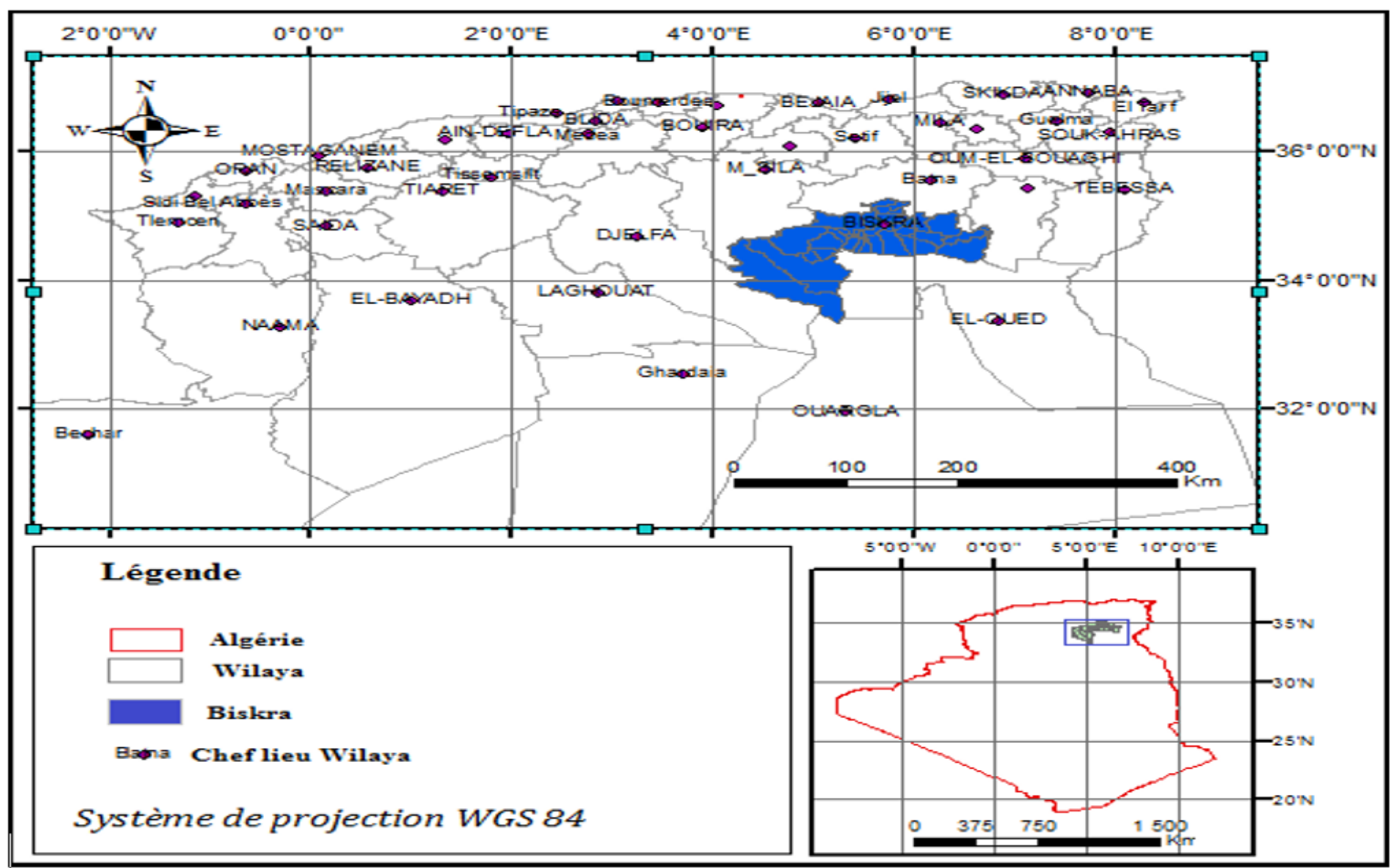

Figure 1 

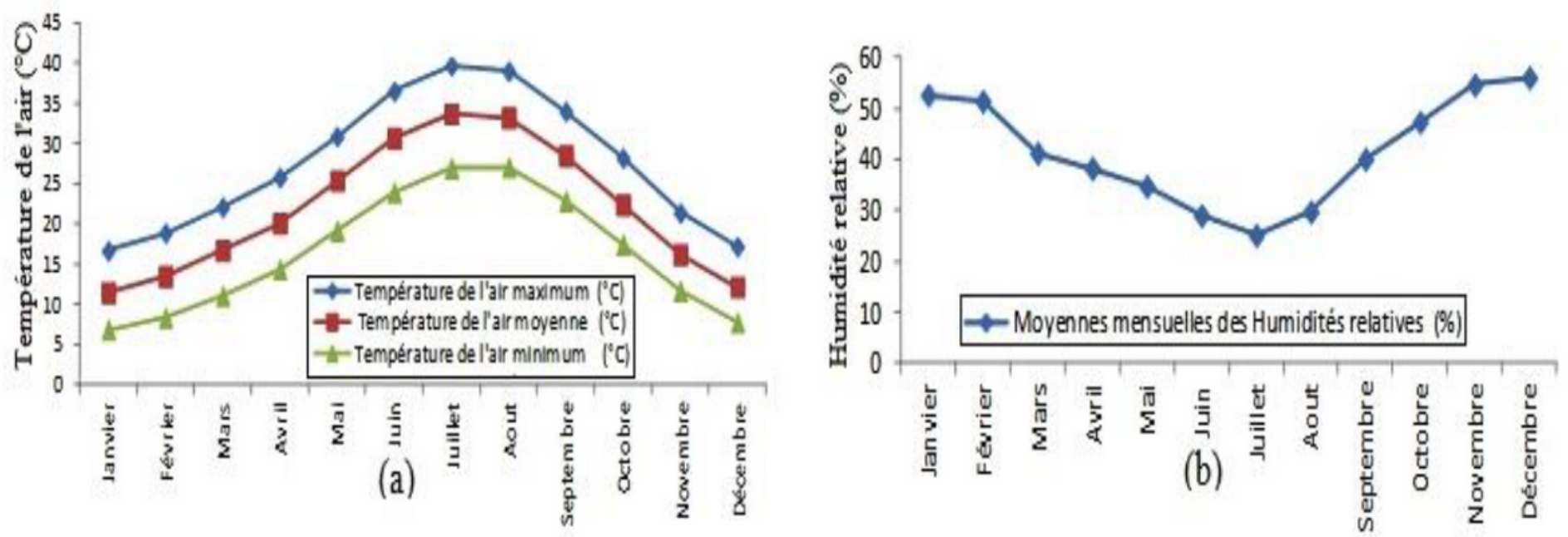

Figure 2

(a) Graph relating to the monthly average air temperature for the period 67-2005 (Source: Biskra weather station data). (b) Graph relating to the monthly average relative humidity for the period 1975-1984 (Source: National climatological atlas data).
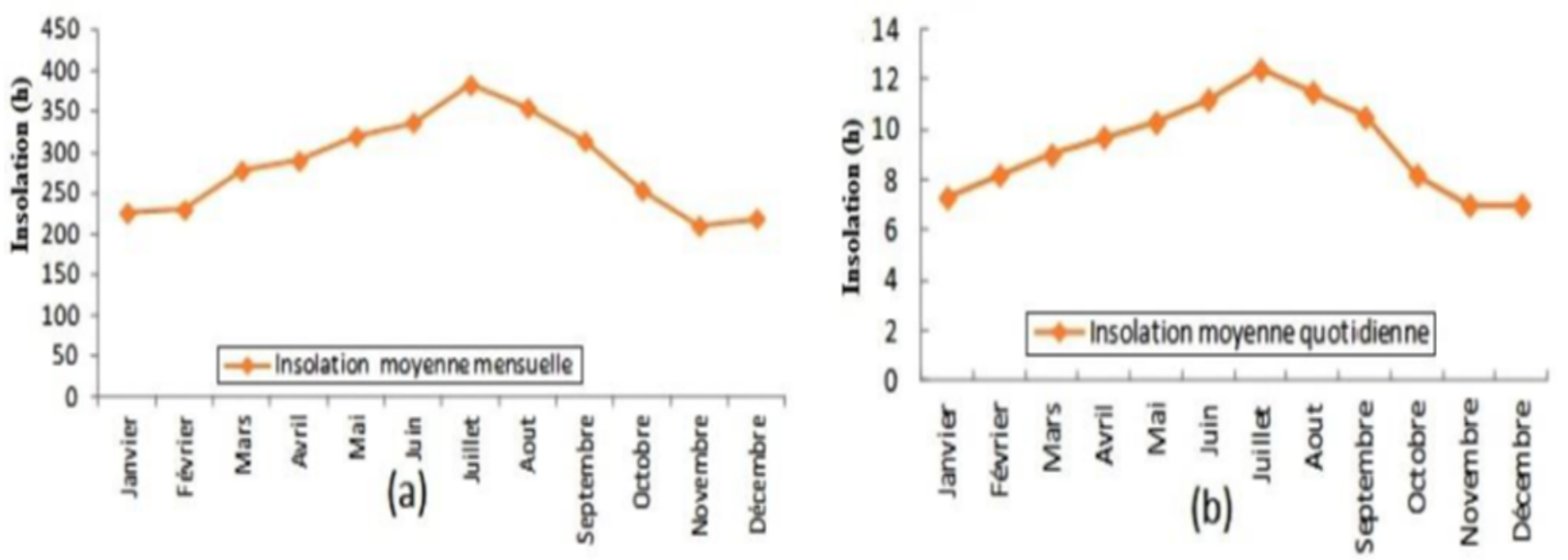

Figure 3

(a) Plot relative to the average monthly insolation duration; (b) plot relative to the average daily insolation duration of Biskra [4]. 

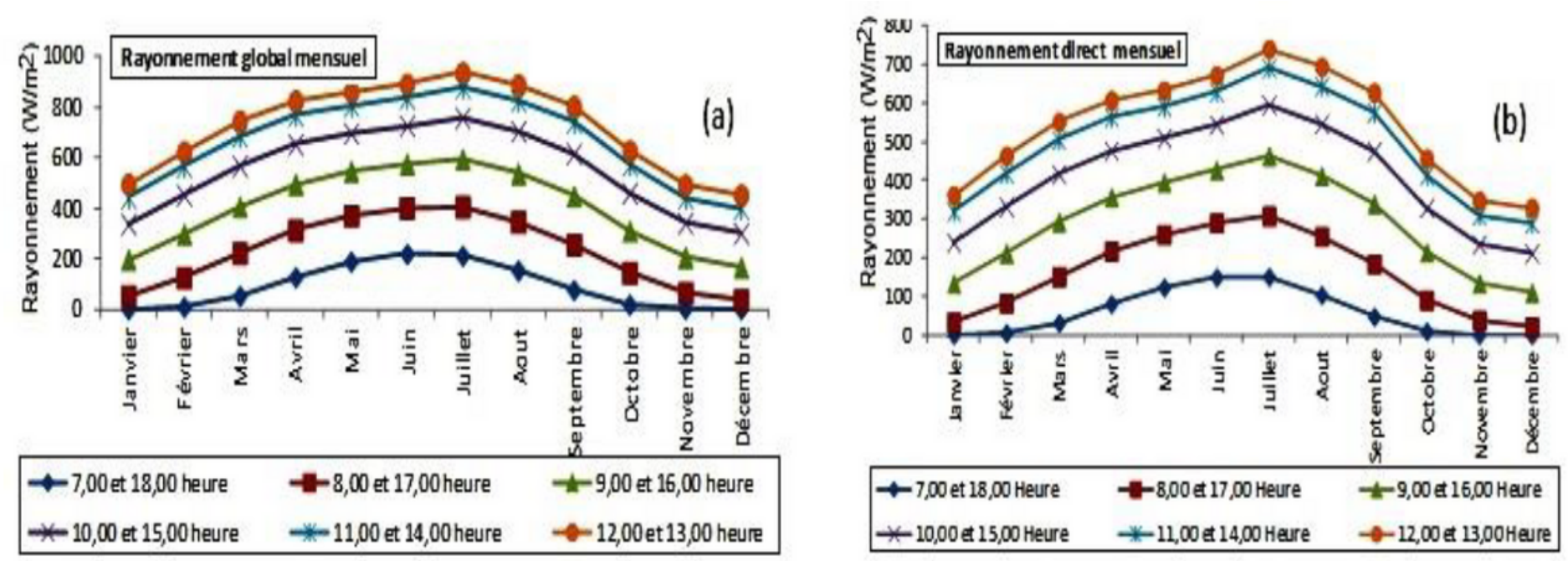

\section{Figure 4}

(a) Plot of incident radiation on a horizontal plane per hour of an average sunny day for each month of Biskra (monthly global ray). (b) Graph relating to the incident radiation on a horizontal plane per hour on an average sunny day for each month of Biskra (monthly direct ray) [5]. 

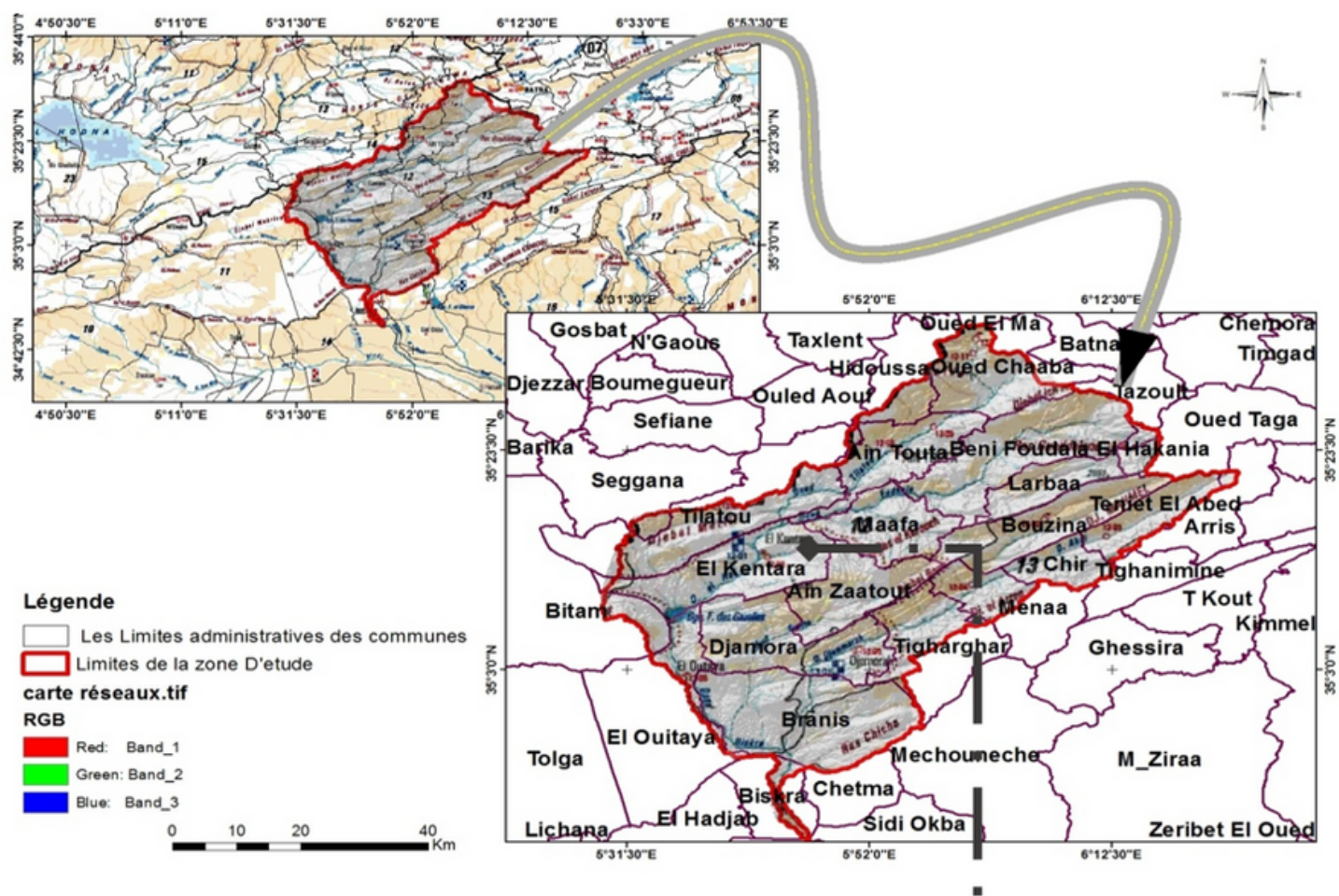

A

B

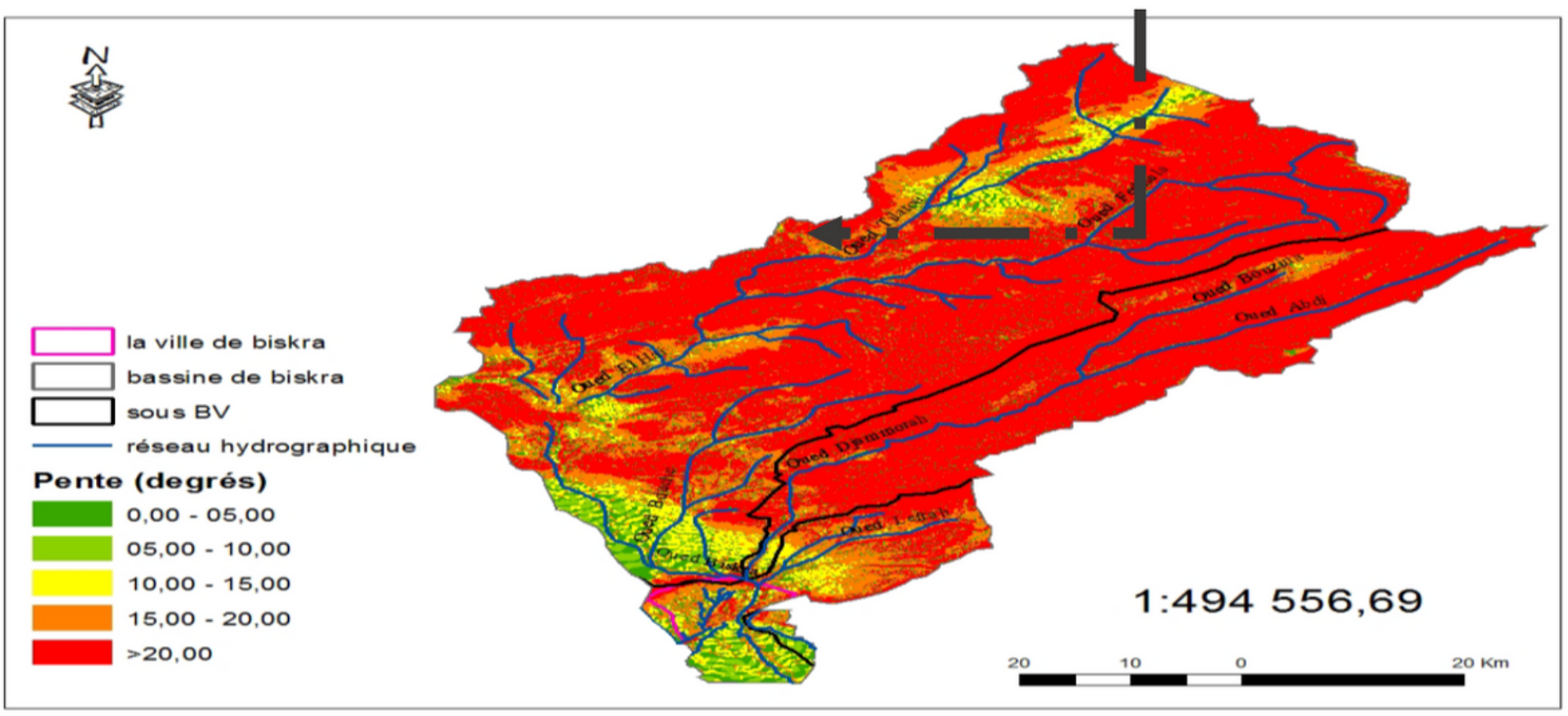

Figure 5

(a) geographical location of the Wadi Biskra watershed. (b) Sketch of the slopes of the Wadi Biskra watershed. 


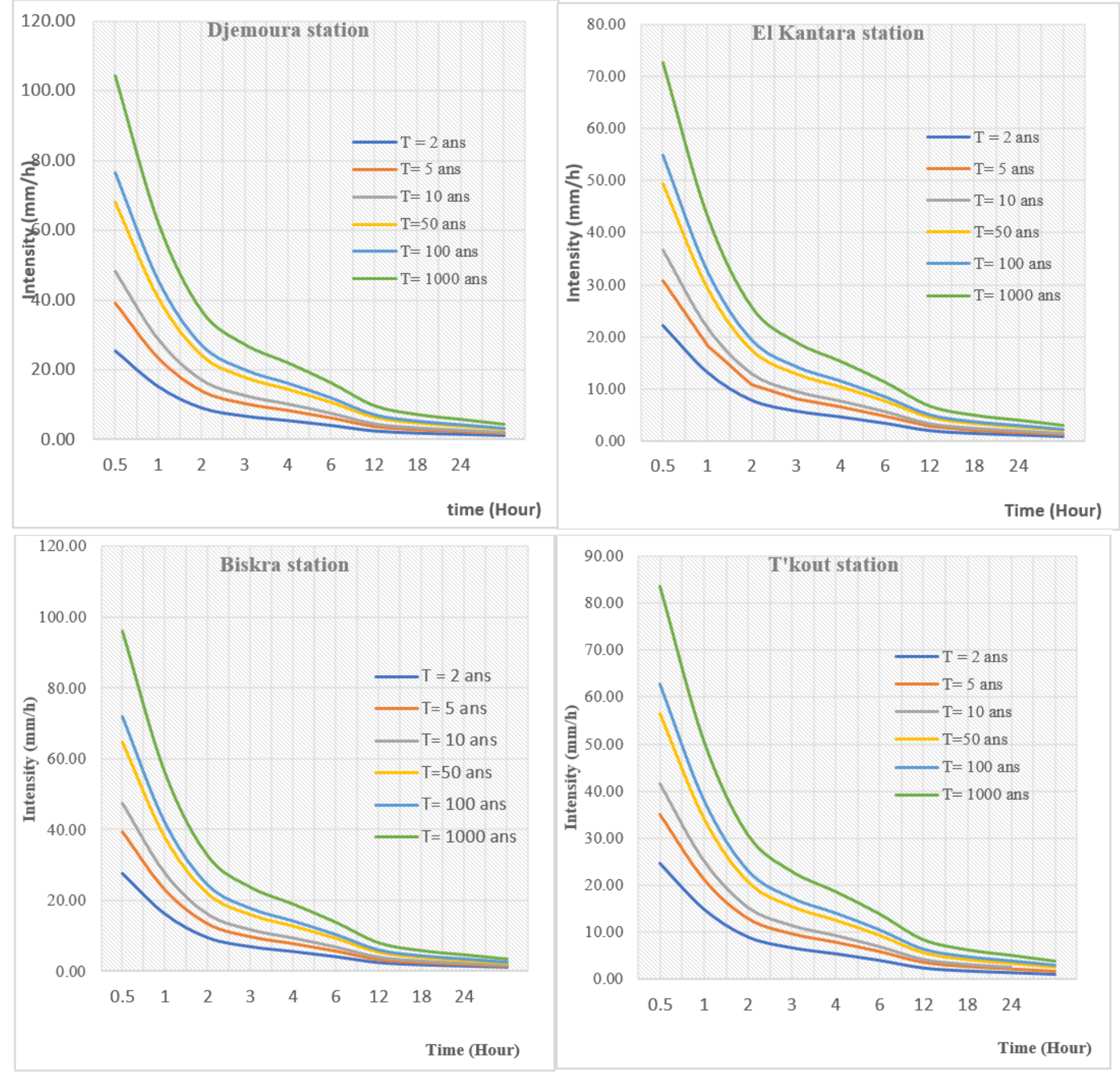

\section{Figure 6}

IDF curves of the different stations of the Wadi Biskra watershed 

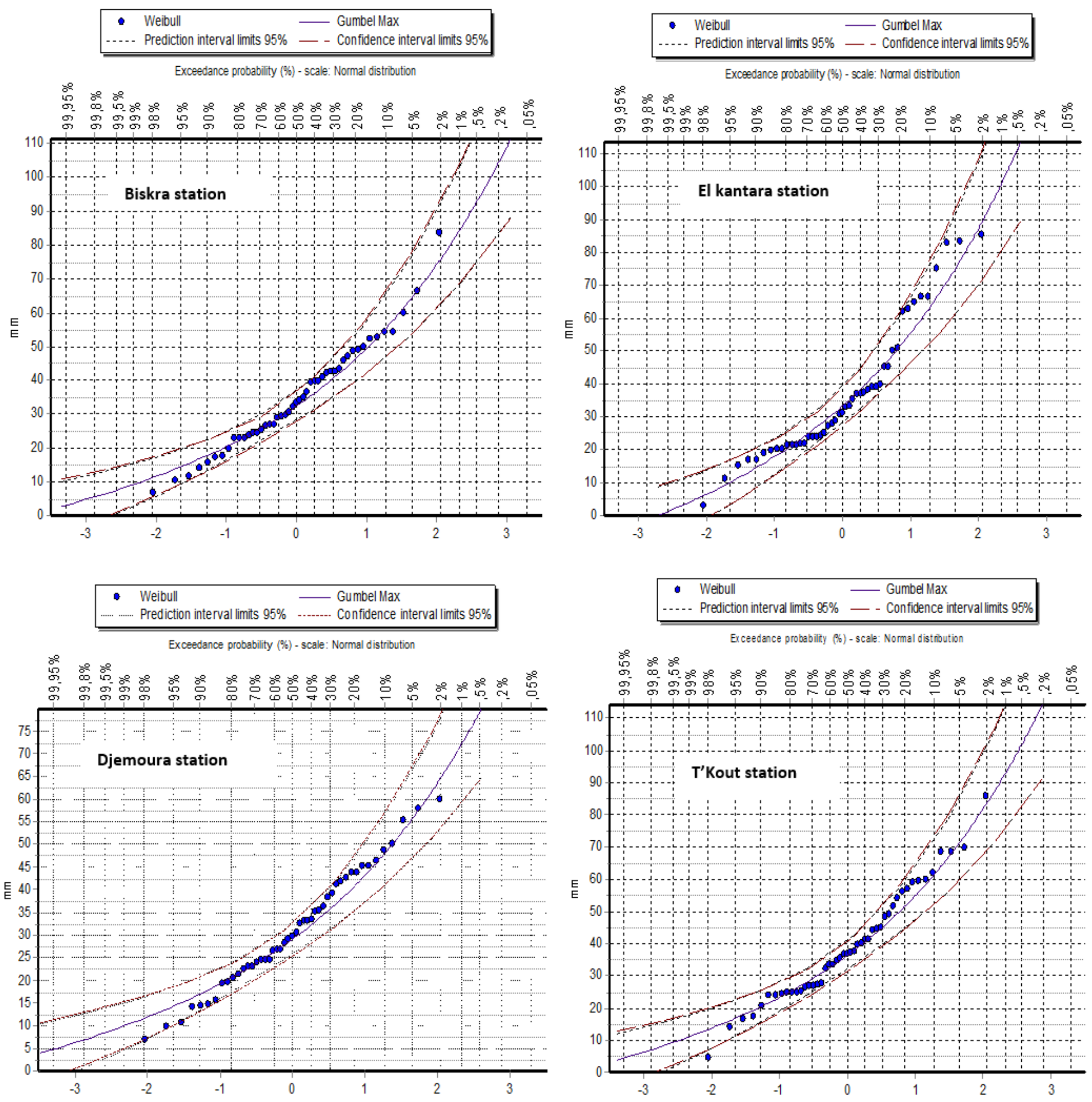

\section{Figure 7}

Adjustment of maximum daily rainfall to the Gumbel law at Biskra, Djemoura, El kantara, and T'Kout stations for the period $(1968 / 2014)$ 

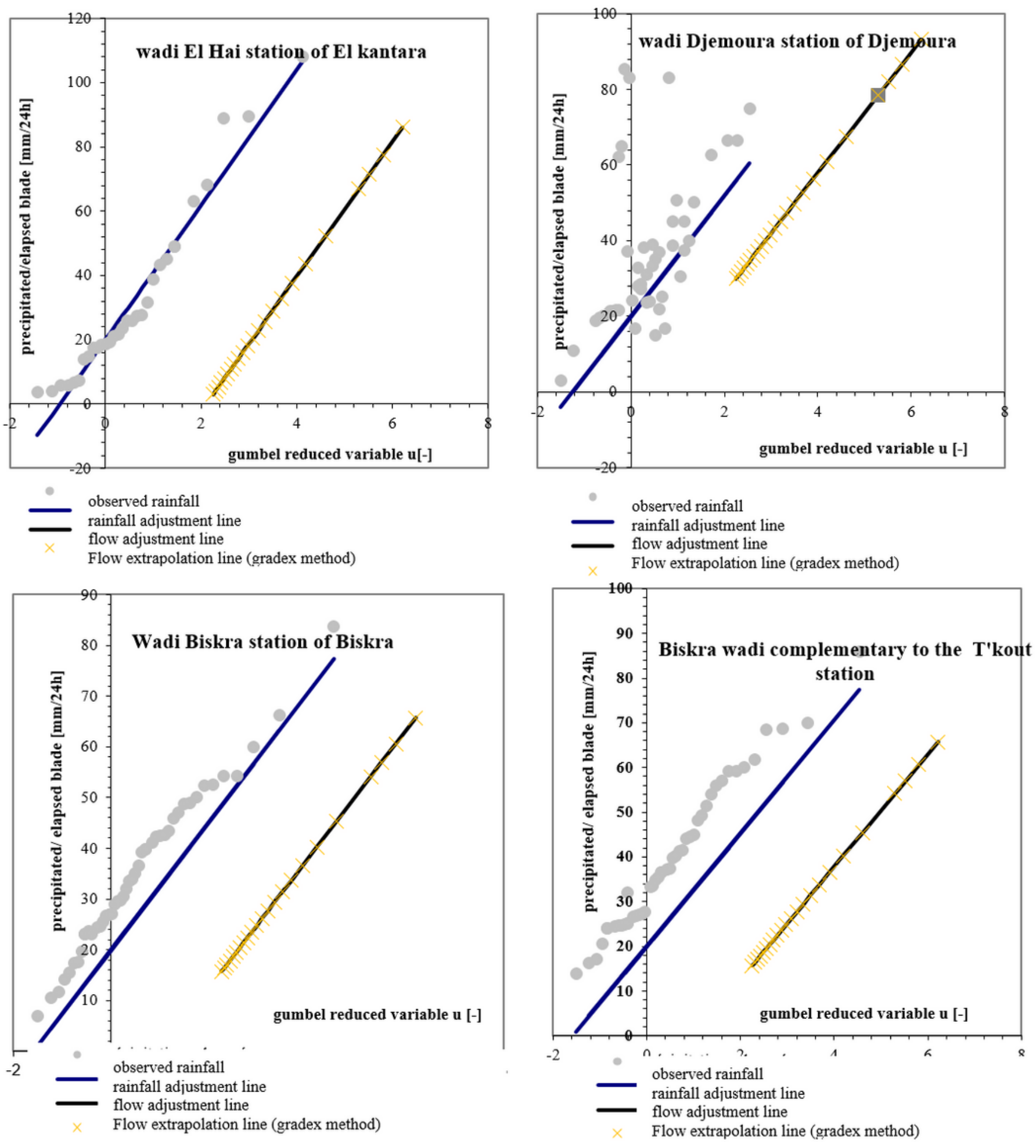

\section{Figure 8}

Graphic adjustment for rainfall and extrapolation line for the flows of Wadi Biskra and its ensemble 

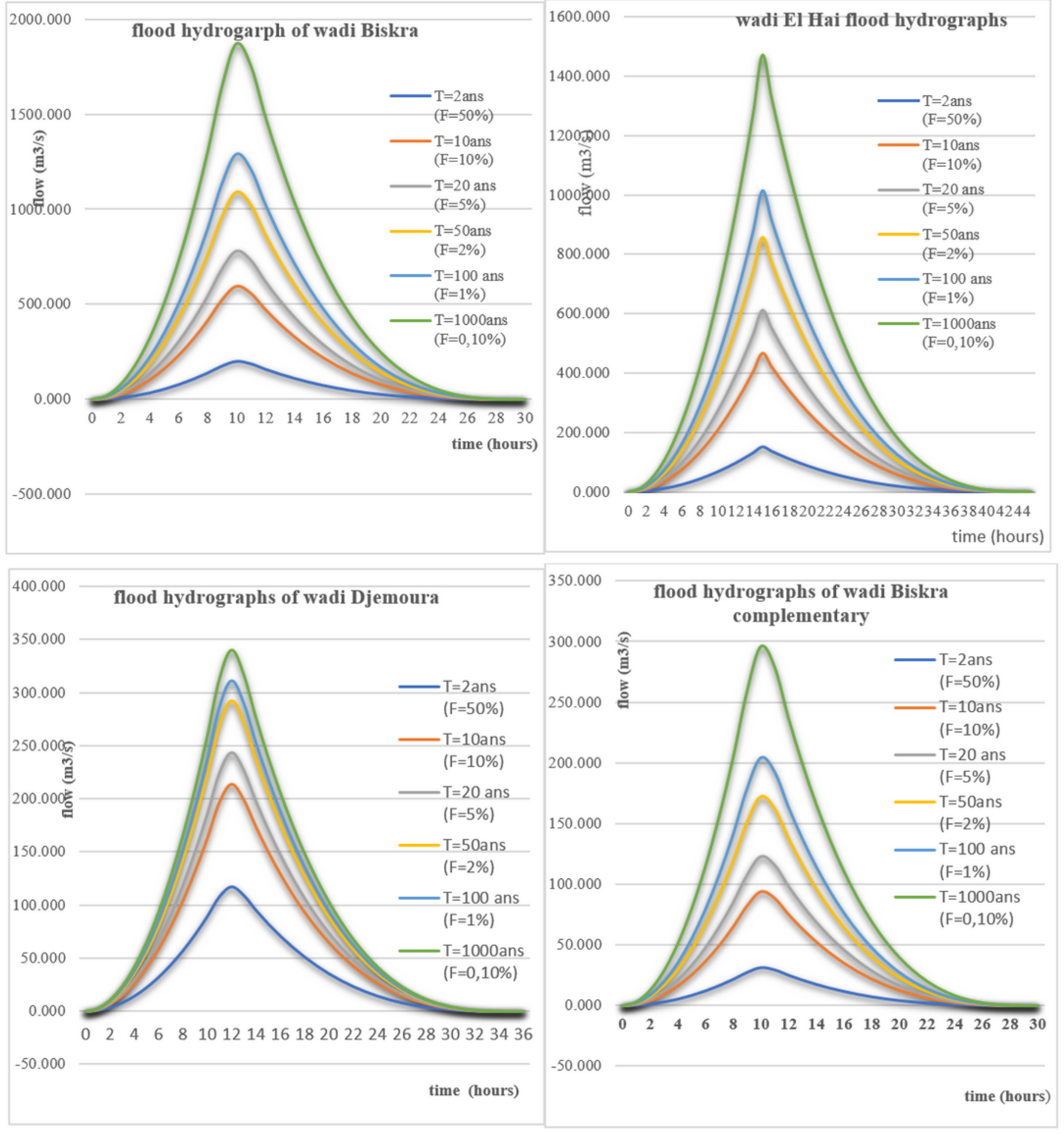

Figure 9

Flood hydrographs for the Wadi Biskra and its catchment areas 